\title{
Effect of bentonite modified by silane on rubber blends properties
}

\author{
Zuzana Mičicová ${ }^{* 1}$, Slavomíra Božeková $^{1}$, Mariana Pajtášová $^{1}$, Darina Ondrušová ${ }^{1}$ \\ ${ }^{1}$ Alexander Dubček University of Trenčín, Faculty of Industrial Technologies in Púchov, I. Krasku \\ 941/30, 02001 Púchov, Slovak Republic
}

\begin{abstract}
The presented paper deals with the preparation of bentonite modified by silane and its application into polymer matrix. Natural bentonite was modified with 3-(Trimethoxysilyl) propyl-methacrylate in two different solutions. These two solutions had the same composition (ethanol, water and 3-(Trimethoxysilyl) propylmethacrylate) but in one solution, $\mathrm{pH}$ was modified. These bentonites modified by silane were characterized by Fourier transform infrared spectroscopy. The modified bentonites were mixed into rubber matrix as partial replacement of commonly used filler - carbon black of the N339 type. The polymer blends were investigated from the aspect of the rheological and curing characteristics (minimum torque $\mathrm{M}_{\mathrm{L}}$, maximum torque $\mathrm{M}_{\mathrm{H}}$, optimum time of cure $\mathrm{t}_{(\mathrm{c} 90)}$, processing safety of blend $\mathrm{t}_{\mathrm{s}}$ ). Moreover, the quality of the silanization reactions was investigated. Measurements were done using PRPA 2000.
\end{abstract}

Keywords: bentonite, silanization, fillers, curing characteristics, silane

\section{Introduction}

Surface modification is a good way to improve the dispersive properties and increase the surface activity of filler. The most of particulate fillers are inorganic and their surfaces have poor compatibility with hydrocarbon polymers. Among other effects, this can result in processing problems, such as high viscosity, poor dispersion and poor mechanical properties $[1,2]$.

In order to obtain a positive effect of the surface treatment, it is necessary to select the suitable modifier for the treatment, with respect to the filler and the matrix. Organosilanes elong among the most frequently used surface modifiers [1, 3, 4].

In the material research of the polymeric materials, the current trend includes research of polymers in combination with clay minerals. The economic as well as environmental aspects are the reasons for the mentioned investigation of clay minerals with polymers $[5,6]$. Clay fillers, in contrast to carbon black, have lower compatibility with the rubber matrix, and for this reason, the silane-binding agents are used to improve the interaction of the clay filler with the rubber chains $[1,7,8]$.

\footnotetext{
* Corresponding author: zuzana.micic@gmail.com

Reviewers: Andrej Czán, Eva Tillová
} 
Surface modification of clay fillers has attracted much attention because the obtained products exhibit properties suitable for many applications in material science and environmental engineering Modification is generally considered to be an attractive and effective method because due to this method, the clay particles (e.g. kaolin and montmorillonite) are more compatible with rubber matrix [9].

\section{Experimental}

\subsection{Preparation of modified bentonite}

The natural bentonite was used as initial material to be modified bentonite and this initial material was extracted from the locality called Jelsovy Potok. The chemical composition of natural bentonite is given in Tab. 1 while content of montmorillonite was $80 \%$. Before the surface modification, natural bentonite was dried in dryer at the temperature of $80 \pm 5^{\circ} \mathrm{C}$ to get constant weight. Then, this silane type was chosen to modify the bentonite surface: 3-(Trimethoxysilyl) propyl-methacrylate (TSPMA).

Table 1. Composition of natural bentonite in Weight \%

\begin{tabular}{|c|c|c|c|c|c|c|c|c|}
\hline Oxide & $\mathrm{SiO}_{2}$ & $\mathrm{Al}_{2} \mathrm{O}_{3}$ & $\mathrm{Fe}_{2} \mathrm{O}_{3}$ & $\mathrm{TiO}_{2}$ & $\mathrm{CaO}$ & $\mathrm{MgO}$ & $\mathrm{K}_{2} \mathrm{O}$ & $\mathrm{Na}_{2} \mathrm{O}$ \\
\hline Weight \% & 59 & 20 & 0.3 & 0.2 & 2.2 & 4 & 0.7 & 0.4 \\
\hline
\end{tabular}

The modification was carried out for two different solutions. The first solution consisted of ethanol-water mixture (70:30) with subsequent addition of silane (3 wt parts of modifying agent per $100 \mathrm{wt}$ parts of filler) [9, 10]. The second solution had the same composition but its $\mathrm{pH}$ was treated with acetic acid. A bentonite sample was then added to both solutions and the two mixtures were stirred at $60{ }^{\circ} \mathrm{C}$ and $450 \mathrm{rpm}$ for 2 hours. The resulting suspensions were filtered under reduced pressure and the prepared samples were dried in dryer at the temperature of $80 \pm 5{ }^{\circ} \mathrm{C}$. For further experiments, two prepared modified bentonites with a particle size $<25 \mu \mathrm{m}$ were used.

\subsection{Preparation of rubber blends}

The five tread blends were prepared by two-step mixing in laboratory mixer of Brabender type with chamber volume of $80 \mathrm{~cm}^{3}$ and mixing process involved 60 revolutions per minute. The proper order of the steps in relation to additives and cure system was performed as it was predetermined. The specification of tread blends is given in Table 2 .

Table 2. Specification and ratio of fillers

\begin{tabular}{|c|c|c|}
\hline blends & Filler & ratio of fillers \\
\hline $\mathrm{R}$ & - & - \\
\hline $\mathrm{S}$ & carbon black & 1 \\
\hline $\mathrm{SB}$ & carbon black + unmodified bentonite & $3: 1$ \\
\hline $\mathrm{SBM}$ & carbon black + modified bentonite by silane agent MPSTA & $3: 1$ \\
\hline $\mathrm{SBM}+\mathrm{pH}$ & carbon black + modified bentonite by silane agent MPSTA $+\mathrm{pH}$ & $3: 1$ \\
\hline
\end{tabular}




\subsection{Characterization of the modified bentonite}

The detailed characteristics of unmodified and modified bentonites were obtained by measurements based on spectral (FTIR) analysis. The infrared absorption spectra of investigated unmodified and modified bentonites were obtained with Tensor 27 FTIR spectrometer in the 4000-400 $\mathrm{cm}^{-1}$ spectral range with the resolution of $4 \mathrm{~cm}^{-1}$. The $\mathrm{KBr}$ disk technique was used.

\subsection{Characterization of rubber blends}

The processing capacity of rubber blend can be predicted using their curing characteristics. The rheological properties and curing characteristics were investigated by help of PRPA 2000 at the temperature of $150{ }^{\circ} \mathrm{C}$ during $30 \mathrm{~min}$. The quality of the silanization reactions was investigated by PRPA 2000 at temperature of $100{ }^{\circ} \mathrm{C}$, frequency of $100 \mathrm{CPM}$ and at strain in the range of (1-450) \%.

\section{Results and discussion}

\subsection{Modified bentonite}

IR spectroscopy is a well-known method to identify the functional groups and to make quantitative analysis. The IR spectra can commonly provide useful information on the surface modification of the bentonite. The FTIR spectra of the unmodified and modified bentonites are shown in Figure 1 and 2. The main peaks from the observed FTIR spectra of the unmodified and modified bentonites are summarized in Table 3.

Table 3. Selected stretching vibrations $\left(\mathrm{cm}^{-1}\right)$ of the modified bentonite

\begin{tabular}{|c|c|c|c|}
\hline Type of vibrations & SB & SBM & SBM + pH \\
\hline$v(\mathrm{Al}-\mathrm{OH})$ & 3627 & 3629 & 3628 \\
\hline$v(\mathrm{H}-\mathrm{O}-\mathrm{H})$ & 3454 & 3457 & 3452 \\
\hline$v_{\text {as }}\left(\mathrm{CH}_{3}\right)$ & - & 2958 & 2960 \\
\hline$v_{\mathrm{as}}\left(\mathrm{CH}_{2}\right)$ & - & 2931 & 2924 \\
\hline$v_{\mathrm{s}}\left(\mathrm{CH}_{3}\right)$ & - & 2895 & 2854 \\
\hline$v(\mathrm{C}-\mathrm{O})$ & - & - & 1126 \\
\hline$v(\mathrm{Si}-\mathrm{O})$ & 1056 & 1038 & 1035 \\
\hline
\end{tabular}

In the case of the all samples, the band at $3627-3629 \mathrm{~cm}^{-1}$ corresponds to the stretching vibration of the hydroxyl groups are bonded with aluminium atoms of the clay mineral. The broad band at $3452-3457 \mathrm{~cm}^{-1}$ is assigned to hydroxyl stretching vibrations of the $\mathrm{H}-\mathrm{O}-\mathrm{H}$ groups, of the free and interlayer water molecules on montmorillonite clay, and the band at $1035-1056 \mathrm{~cm}^{-1}$ is associated with the stretching vibrations of the $\mathrm{Si}-\mathrm{O}$ groups. The intensity of the absorption band decreased with surfactant modification, and it gives evidence about a lower hydrophilicity in the interlayer region. For SBM and SBM $+\mathrm{pH}$ samples, the bands at $2854-2960 \mathrm{~cm}^{-1}$ are assigned to the $\mathrm{C}-\mathrm{H}$ stretching vibrations of aliphatic $\mathrm{CH}_{2}$ and $\mathrm{CH}_{3}$ groups, indicating the presence of the organic component (silane) $[11,12]$. 


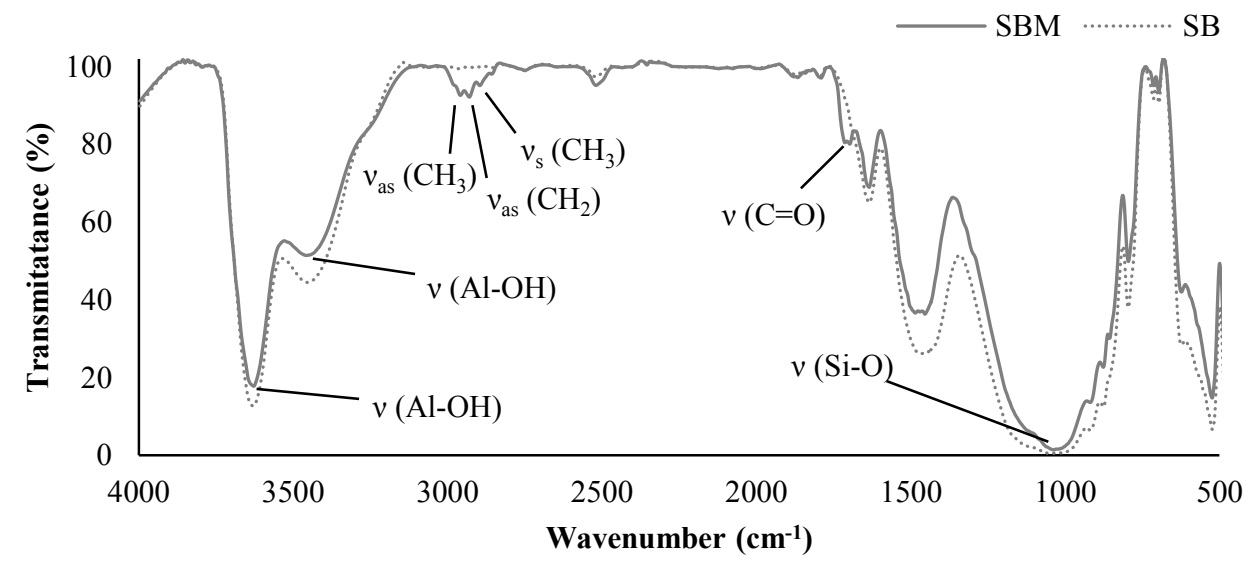

Fig. 1. IR spectra of sample SBM and SB

In case $\mathrm{SBM}+\mathrm{pH}$ sample, the band at $1126 \mathrm{~cm}^{-1}$ is assigned to stretching vibrations of the $\mathrm{C}-\mathrm{O}$ groups, indicating the presence of the organic component (silane) [11, 12].

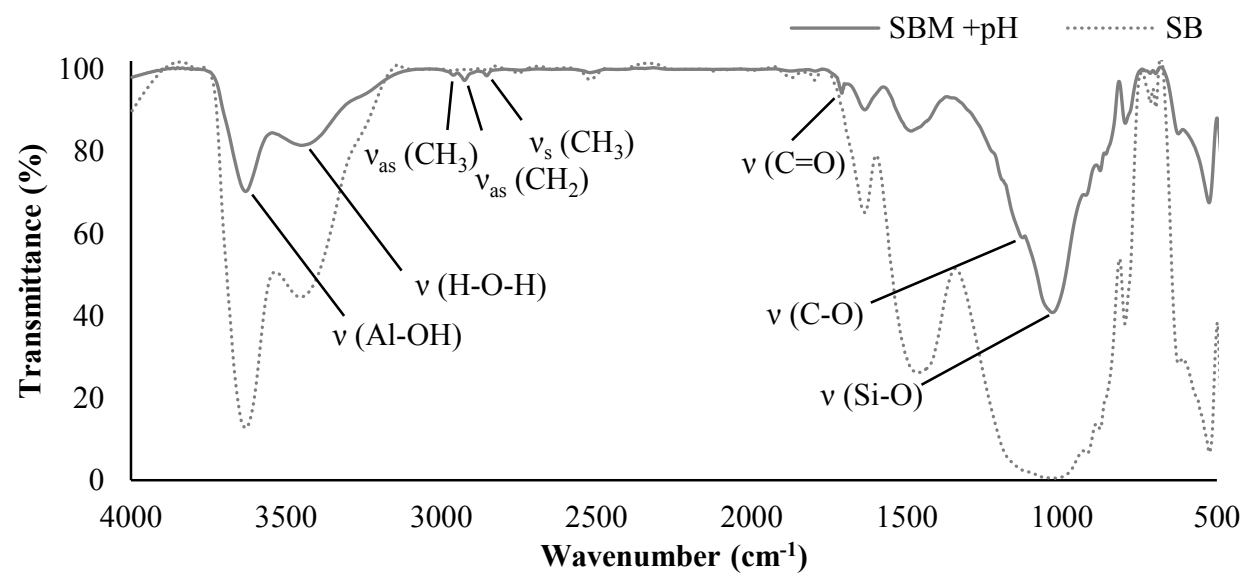

Fig. 2. IR spectra of sample $\mathrm{SBM}+\mathrm{pH}$ and $\mathrm{SB}$

\subsection{Cure behaviour of the rubber blends}

The effect of the modified filler on the course of sulphur curing process of tread blends was evaluated on the basis of curing characteristics. Based on the evaluated rheometric results of curing curves, the values of rheometric properties and curing characteristics are shown in Table 4. Graphical presentation of the curing curves is shown in Figure 3. 
Table 4. Rheological and curing characteristics of rubber blends

\begin{tabular}{|c|c|c|c|c|}
\hline blends & $\mathbf{M}_{\mathbf{L}}(\mathbf{d N} \cdot \mathbf{m})$ & $\mathbf{M}_{\mathbf{H}}(\mathbf{d N} \cdot \mathbf{m})$ & $\mathbf{t}_{\mathbf{s}}(\mathbf{m i n})$ & $\mathbf{t}_{\mathbf{c}(\mathbf{9 0})}(\mathbf{m i n})$ \\
\hline $\mathrm{R}$ & 1.69 & 8.78 & 2.30 & 6.95 \\
\hline $\mathrm{SB}$ & 1.47 & 6.88 & 3.55 & 12.43 \\
\hline $\mathrm{SBM}$ & 1.36 & 6.94 & 3.64 & 11.78 \\
\hline $\mathrm{SBM}+\mathrm{pH}$ & 1.48 & 6.86 & 4.56 & 14.23 \\
\hline
\end{tabular}

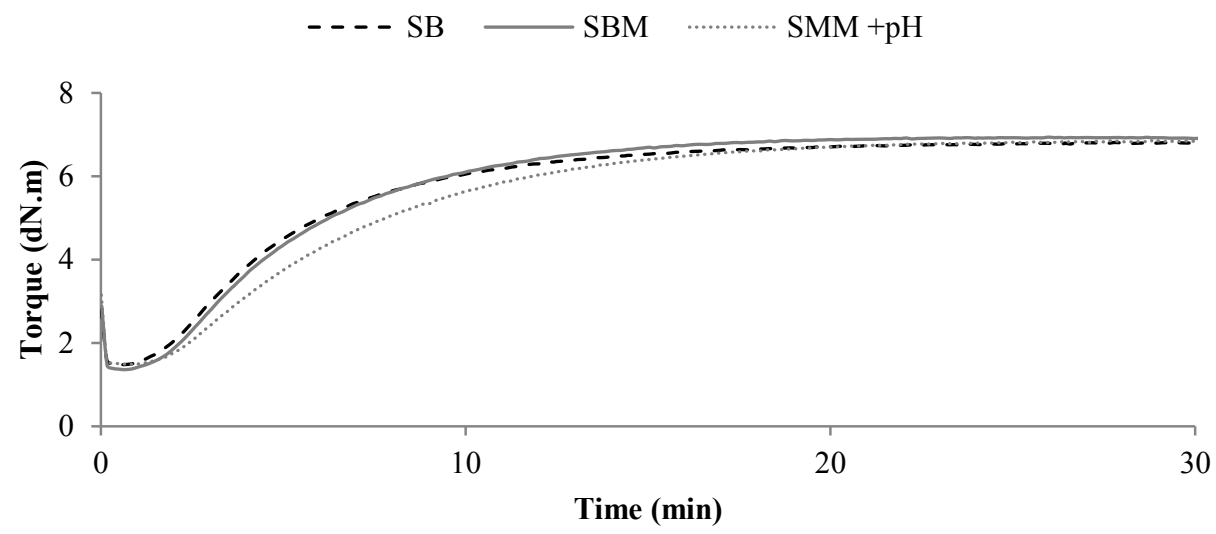

Fig. 3. Cure records of $\mathrm{SB}, \mathrm{SBM} \mathrm{SBM}+\mathrm{pH}$ and $\mathrm{R}$ blends

The values of minimum torque and maximum torque for tread blend are lower in comparison with the reference blend values. The decrease of values indicates lower viscosity as well as lower stiffness of the tread blends at the beginning and end of the cure. From Table 4, it can be seen that the values of processing safety of tread blends are higher in comparison with the reference blend values. It can be assumed that the content of fillers in the rubber blends has a positive effect on processing safety, and it may affect the processing properties of the blends. In the case the optimum time, blends exhibited higher values in comparison with reference blend values [5].

\subsection{The quality of the silanization reactions}

The test was divided into two parts where the first part of the filler-filler interaction was determined at low strain $(1 \%)$ and by this way, the size of the elastic moment $\left(\mathrm{G}^{\prime}\right)$ was recorded. In the second part, there was the higher strain $(450 \%)$ and using this strain, the size of the torque moment ( $\mathrm{S}^{\prime}$ ) was determined (cohesion polymer network). The lower the filler-filler interaction, the better the dispersion of the filler used. This results in a higher efficiency of the silanization reaction. The torque value at high deformation angles indicates whether the effect of temperature in the silanization reaction could cause undesired curing of blend. The torque value should be as low as possible, otherwise there will be an increase in the degradation of the silane $[13,14]$. The results are shown in Table 5 and depicted graphically in Figure 4. 
Table 5. Values of $\mathrm{G}^{\prime}$ and $\mathrm{S}^{\prime}$ for determination of the silanization reaction quality

\begin{tabular}{|c|c|c|}
\hline Blends & $\mathbf{G}^{\prime} \mathbf{( 1 \% )}$ & $\mathbf{S}^{\prime} \mathbf{( 4 5 0 \% )}$ \\
\hline $\mathrm{SBM}$ & 230.34 & 9.93 \\
\hline $\mathrm{SBM}+\mathrm{pH}$ & 247.76 & 11.15 \\
\hline
\end{tabular}

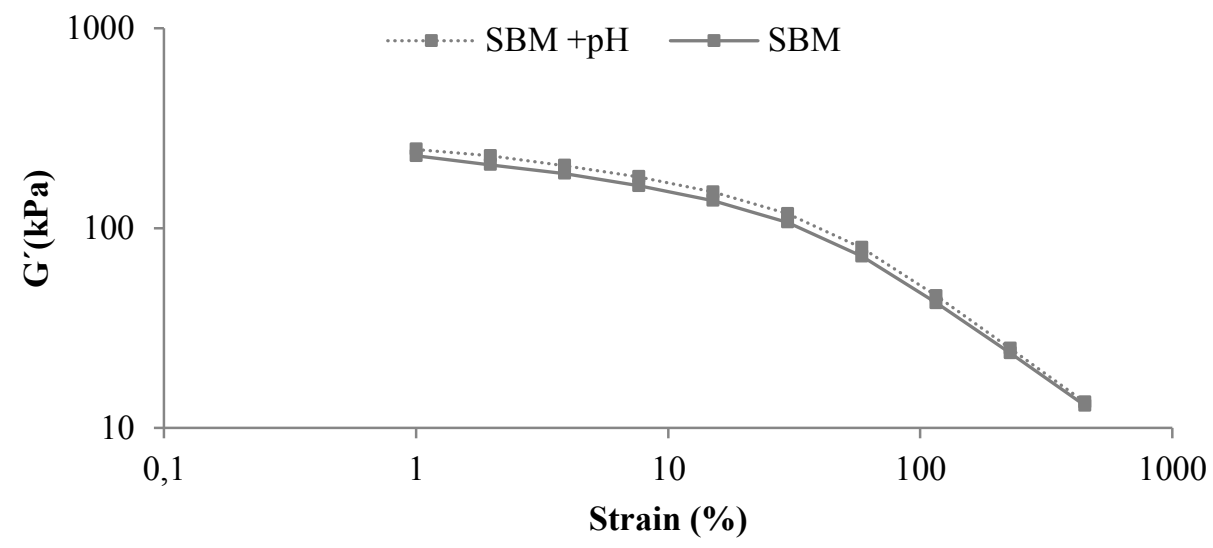

Fig. 4. The dependence of $\mathrm{G}^{\prime}$ on strain for SBM and SBM $+\mathrm{pH}$ blends

From the measured results, the lowest value of the elastic modulus, and thus the lowest efficiency of the silanization reaction, showed a SBM blend and it indicates that the filler is well dispersed in the polymer matrix.

\section{Conclusions}

This study was based on modification of bentonite which was used as partial replacement of the high reinforcing filler - carbon black of N339 type. The polymer blends with the modified bentonites were used as a partial carbon black replacement and they were investigated from the aspect of rheological properties and curing characteristics. In addition, the quality of silanization reaction was investigated. The determination of the quality of silanization reaction shows that there is the lowest value of the elastic modulus $\mathrm{G}(1 \%)$ and thus there is the highest efficiency of the silanization reaction in relation to blend containing filler based on modified bentonite (SBM) and it leads to facts that the filler is well dispersed in the polymer matrix.

This work was supported by the Slovak Grant Agency KEGA 007TnUAD-4/207, VEGA 1/0589/17, VEGA $1 / 0649 / 17$ and resulted from the project "Center for quality testing and diagnostics of materials", ITMS code 26210120046 relating to the Operational Program Research and Development funded from European Fund of Regional Development.

\section{References}

1. Z. Mičicová, S. Božeková, M. Pajtášová, D. Ondrušová, Povrchová modifikácia bentonitu (3-aminopropyl)trietoxysilánom a jeho vplyv na reologické vlastnosti v polymérnej matrici. Hutnické listy 5, 95-99 (2016) 
2. P. Djomgoue, D. Njopwouo, FT-IR Spectroscopy Applied for Surface Clays Characterization. Journal of Surface Engineered Materials and Advanced Technology 3, 275-282 (2013)

3. A.M. Motawie, M.M. Madany, A.Z. El-Dakrory H.M Osman, E.A. Ismail, M.M. Badr, D.A. El-Komy, D.E. Abulyazied, Physico-chemical characteristics of nano-organo bentonite prepared using different organo-modifiers. Egyptian Journal of Petroleum 23, 331-338 (2014)

4. D.S. Kim, V. Dhand, K.Y. Rhee, S.J. Park, Study on the Effect of Silanization and Improvement in the Tensile Behavior of Graphene-Chitosan-Composite. Polymers 7, 527-551 (2015)

5. M. Pajtášová, Z. Mičicová, D. Ondrušová, B. Pecušová, A. Feriancová, L. Raník, S. Domčeková, Study of properties of fillers based on natural bentonite and their effect on the rubber compounds. Procedia Engineering 177, 470-475 (2017)

6. S. Palaty, R. Joseph, Synergism of Xanthate/Dithiocarbamate Accelerator in Carbon Black Filled NR Compounds. Iranian Polymer Journal 13, 85-91 (2004)

7. S. Khaje, M. Jamshidi, The Effect of Aging and Silanization on the Mechanical Properties of Fumed Silica-based Dental Composite. Journal of Dental Biomaterials 2, 124-132 (2015)

8. A. Khoshniyat, A. Hashemi, A. Sharif, J. Aalaie, C. Duobis, Effect of surface modification of bentonite nanoclay with polymers on its stability in an electrolyte solution. Polymer Science Series B 54, 61-72 (2012)

9. S. Božeková, D. Ondrušová, Z. Mičicová, M. Pajtášová, R. Moravčík, L. Buňová, Effect of modified alternative filler on the properties of rubber compounds. Procedia Engineering 136, 245-250 (2016)

10. S. Božeková, Z. Mičicová, D. Ondrušová, M. Pajtášová, Vplyv modifikovaného alternativneho plniva silánom Bis3-(triethoxysilyl)-tetrasulphid na vlastnosti gumárenských zmesí. Hutnické listy 5, 48-52 (2016)

11. M.E. Parolo, G.R. Pettinari, T.B. Musso, M.P. Sánchez-Izquierdo, L.G. Fernández, Characterization of organo-modified bentonite sorbents: The effect ofmodification conditions on adsorption performance. Applied Surface Science 320, 356-363 (2014)

12. C.H. Champos, B.F. Urbano, B.L. Rivas, Synthesis and characterization of organicinorganic hybrid composites from poly(acrylic acid)-[3-(trimethoxysilyl)propyl methacrylate] $-\mathrm{Al}_{2} \mathrm{O}_{3}$. Composites, Part B, 57, 1-7 (2014)

13. O. Wilczynski, Vlivy odporu pneumatiky vs. Životní prostředí. Plasty a kaučuk 46, 6873 (2009)

14. D. Ondrušová, S. Božeková, M. Pajtášová, Z. Mičicová, I. Labaj, Modifikácia klinoptilotitu, jeho aplikácia do gumárenských zmesí a štúdium priebehu silanizačnej reakcie. Hutnické listy 5, 53-57 (2016) 